\title{
THE EFFECT OF SYMPATHETIC BLOCKADE OR HYPERVENTILATION ON EPINEPHRINE-INDUCED CARDIAC ARRHYTHMIAS DURING: ANAESTHESIA WITH HALOTHANE AND MÉTHÓXYFLURANE*
}

\author{
JaCob S. ISRAEL; M.D., Allen B. DobKin, M.D., AND \\ Henry J. Robidoux, JR., B.S. $\dagger$
}

MANY DRLGS and diverse techniques have been $/$ used to reduce arrhythmias during general anaesthesia. Spinal and epidural analgesia have been employed to this end during general anaesthesia in an effort to deafferent the adrenals and the sympathetic nervous system in patients with phaeochromocytoma ${ }^{1,2}$ and in patients with uncontrolled thyrotoxicosis. ${ }^{3}$ It has been shown that cardiac arrhythmias are more apt to occur under cyclopropane anaesthesia when the $p \mathrm{CO}_{2}$ is elevated. ${ }^{4}$ This effect was also reported under halothane anaesthesia. ${ }^{5}$ Because of these report's we wondered whether spinal analgesia or hyperventilation would provide a protective effect against induced cardiac arrhythmias during halothane and methoxyflurane anaesthesias by blockade of the sympathetic outflow or perhaps by decreasing endogenous catecholamine production.

A comparison of the epinephrine-induced arrhythmias was made in one group of dogs under anaesthesia with 1 per cent methoxyflurane and with 2 per cent halothane both with and without the previous administration of high spinal analgesia. A second group of dogs were hyperventilated during 1 per cent methoxyflurane and 2 per cent halothane anaesthesia and then given a standard epinephrine chállenge.

\section{METHOD}

Twenty-six acute experiments were performed on 10 mongrel dogs weighing from 9.8 to $21.6 \mathrm{~kg}$. (mean $16.4 \mathrm{~kg}$.) and 16 acute experiments were carried out on the second group of 13 dogs weighing from 8 to $25 \mathrm{~kg}$. (mean $13.2 \mathrm{~kg}$.).

In the fasting state, the dogs were given a sleep dose of $75-250 \mathrm{mg}$. thiopental sodium and 10-20 mg. of succinylcholine chloride to facilitate endotracheal intubation. An infusion of normal saline was started at this time to maintain hydration and to provide a route for the injection of an epinephrine challenge.

Breathing was augmented with a Takaoka respirator ${ }^{6}$ for the maintenance of adequate pulmonary ventilation. The volume of ventilation was set at 4-8 litres per minute, depending on the size of the animal (average minute volume 400 $\mathrm{ml} . / \mathrm{kg}$. body weight). In the second group of dogs respiration was augmented 25 per cent above that in the first group.

The electrocardiogram (lead 2) was recorded on each dog with a clinical electrocardiograph. A control tracing was taken immediately following endotracheal

*From 'the Anesthesia Research Laboratory, Departhent' of Anesthesiology, State University of New York, Upstate Medical Centre, Syracuse, New WYork.

†Medical Student Research Assistant. 
intubation while the animals were being ventilated with 100 per cent oxygen. The dogs were then anaesthetized with 1 per cent methoxyflurane delivered with oxygen from a temperature-calibrated vaporizer (Pentec $\left.{ }^{\circledR}\right)$. At five-minute intervals an electrocardiogram tracing was taken until 25 minutes had elapsed. Then a recording was taken while the epinephrine challenge was being administered and the tracing was continued until it returned to the pre-injection configuration. The epinephrine challenge consisted of an intravenous injection of $0.02 \mathrm{mg}$. of epinephrine $/ \mathrm{kg}$. body weight/second.

After at least two days' rest, the dogs in group I were again anaesthetized with intravenous thiopental sodium and succinylcholine chloride and again a baseline electrocardiogram was taken after endotracheal intubation. Spinal analgesia was then carried out either via the lumbar or the cisternal route. A dose of $2 \mathrm{mg}$. $/ \mathrm{kg}$. of 0.5 per cent procaine in 10 per cent dextrose in water was used in this and all subsequent experiments in this group. This dose does not cause appreciable decrease in heart force and it was felt this dose would cause sympathetic paresis. ${ }^{7}$ After spinal analgesia was effected, an electrocardiogram was taken. Then general anaesthesia was continued with 1 per cent methoxyflurane as in the control period. The dogs were then given the epinephrine, ${ }_{2}$ challenge as described above. In subsequent experiments spinal analgesia was followed by general anaesthesia with 2 per cent halothane delivered from a Fluotec (Mark II) in six of these dogs.

The dogs in group II were given 1 per cent methoxyflurane anaesthesia and they were hyperventilated for 25 minutes preceding an epinephrine challenge. Three of these dogs were subsequently anaesthetized with 2 per cent halothane and hyperventilated for 25 minutes preceding an epinephrine challenge, and three additional "fresh" dogs were treated in the same way.

\section{RESULTS}

The type, incidence, and duration of cardiac arrhythmias that occurred after an epinephrine challenge are summarized in Tables I to IV.

TABLE I

Mean Duration of Arrhythmia due to Epinephrine Chall DURING ANAESTHESIA

\begin{tabular}{|c|c|c|c|c|}
\hline Anaesthetic & No. of dogs & $\begin{array}{c}\text { Onset of } \\
\text { arrhythmia } \\
\text { after } \\
\text { epinephrine } \\
\text { challenge }\end{array}$ & $\begin{array}{c}\text { Duration of } \\
\text { ventricular } \\
\text { tachycardia, } \\
\text { seconds }\end{array}$ & $\begin{array}{l}\text { Total duration } \\
\text { of arrhythmia, } \\
\text { seconds }\end{array}$ \\
\hline $\begin{array}{l}\text { Methoxyflurane } \\
\text { Methoxyflurane } \\
\text { + spinal }\end{array}$ & $\begin{array}{l}10 \\
10\end{array}$ & $\begin{array}{l}12.4 \\
12.6\end{array}$ & $\begin{array}{l}51 \\
27^{*}\end{array}$ & $\begin{array}{l}200 \pm 72 \\
171 \pm 97\end{array}$ \\
\hline Halothane + spinal & 6 & 17.1 & $72 \dagger$ & $\begin{array}{l}\text { At the end of } 5 \text { minutes } \\
\text { still had not returned } \\
\text { to pre-injection level }\end{array}$ \\
\hline
\end{tabular}

*Excluding dog who sustained ventricular fibrillation.

$\dagger$ Duration of tachycardia of the one dog who did not have ventricular fibrillation. 
TABLE II

Incidence of Arrhythmias due to Epinephrine Challenge during Anaesthesia

\begin{tabular}{|c|c|c|c|c|c|c|c|c|c|}
\hline 总 & $\begin{array}{l}\infty \\
0 \\
0 \\
0 \\
0 \\
0 \\
\dot{2}\end{array}$ & 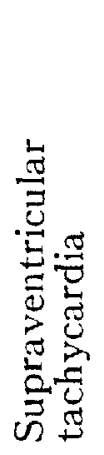 & 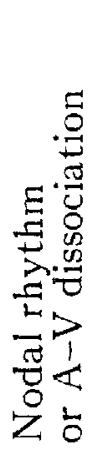 & 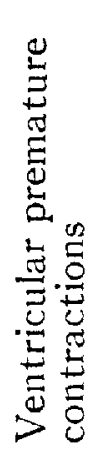 & 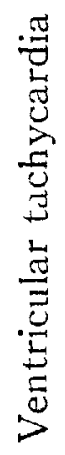 & 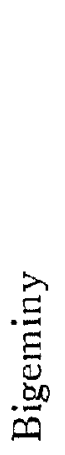 & 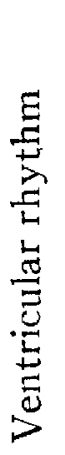 & 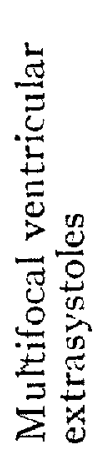 & 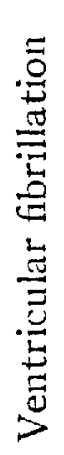 \\
\hline \multirow{3}{*}{$\begin{array}{l}\text { Methoxyflurane } \\
\text { Methoxyflurane } \\
\text { + spinal } \\
\text { Halothane } \\
\text { + spinal }\end{array}$} & 10 & 3 & 8 & 10 & 7 & 5 & 9 & 4 & 0 \\
\hline & $10^{*}$ & 5 & 9 & 9 & 6 & 3 & 8 & 2 & 1 \\
\hline & $6 \dagger$ & 1 & 1 & 1 & 1 & 1 & 1 & 1 & 5 \\
\hline
\end{tabular}

* One dog had ventricular fibrillation-not included in tabulations of other arrhythmias. †Five dogs had ventricular fibrillation-not included in tabulation of other arrhythmias.

TABLE III

Mean Duration of Arrhythmias due to Epinephrine Challenge DURING ANAESTHESIA (ANIMALS HYPERVENTILATED)

\begin{tabular}{|c|c|c|c|c|}
\hline Anaesthetic & No. of dogs & $\begin{array}{l}\text { Onset of arrhythmia } \\
\text { after epinephrine } \\
\text { challenge }\end{array}$ & $\begin{array}{l}\text { Duration of } \\
\text { ventricular } \\
\text { tachycardia }\end{array}$ & $\begin{array}{l}\text { Total duration } \\
\text { of arrhythmia }\end{array}$ \\
\hline $\begin{array}{l}\text { Methoxyflurane } \\
\text { Halothane }\end{array}$ & $\begin{array}{r}10 \\
6\end{array}$ & $\begin{array}{ll}14 & 0 \\
13 & 2\end{array}$ & $100 \underset{*}{10}$ & $167 \pm 38$ \\
\hline
\end{tabular}

*All animals died of ventricular fibrillation.

TABLE IV

Incidence of Arrhythmias due to Epinephrine Challenge during Anaesthesia (ANIMALS HY PERTENTILATED)

\begin{tabular}{|c|c|c|c|c|c|c|c|c|c|}
\hline 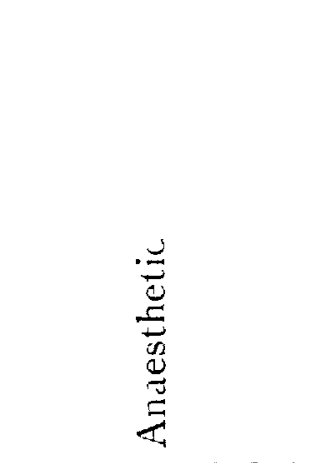 & $\begin{array}{l}0 \\
0 \\
0 \\
0 \\
0 \\
0 \\
\dot{0} \\
\dot{z}\end{array}$ & 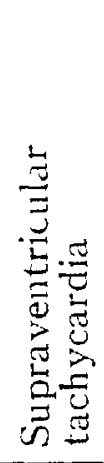 & 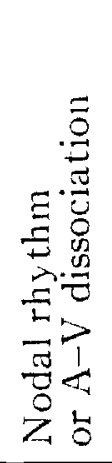 & 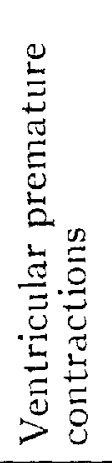 & 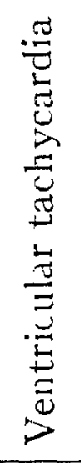 & 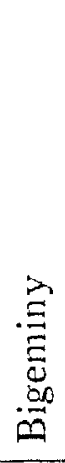 & 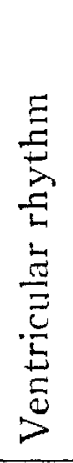 & 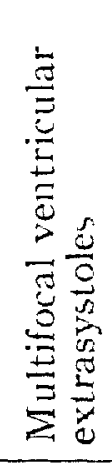 & 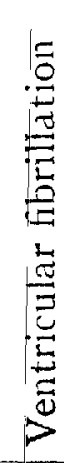 \\
\hline $\begin{array}{l}\text { Methoxyflurane } \\
\text { Halothane }\end{array}$ & $\begin{array}{r}10 \\
6\end{array}$ & 2 & 7 & 10 & 9 & 8 & 10 & 6 & 3 \\
\hline
\end{tabular}

The average heart rate of the dogs in the first group after endotracheal intubation was $155 \pm 54$ for the 10 dogs to be anaesthetized with methoxyflurane (contr $\phi 1$ series), $155 \pm 12$ for the same 10 dogs to be anaesthetized with methoxyflurane after spinal analgesia, and $117 \pm 48$ ffor 6 surviving dogs to be given 
halothane and spinal analgesia. The heart rate after spinal analgesia was $171 \pm 17$ (10 dogs) and $175 \pm 39(6 \mathrm{dogs})$ respectively. At the end of 25 minutes of general anaesthesia the pulse rates were $110 \pm 48,98 \pm 30$, and $77 \pm 8$ in the three series and the onset of arrhythmia was $12.4,12.6$, and 17.1 seconds after the epinephrine challenge respectively.

The heart rate for the dogs in the second group was $164 \pm 51$ and $160 \pm 28$ for the methoxyflurane and halothane animals immediately after endotracheal intubation. After 25 minutes of general anaesthesia and hyperventilation the pulse rates were $118 \pm 16$ and $110 \pm 47$ respectively.

All of the dogs developed serious ventricular arrhythmias after the epinephrine challenge. Seven of the dogs in group I that were anaesthetized with 1 per cent methoxyflurane had ventricular tachycardia of 51 seconds average duration. After spinal analgesia and subsequent 1 per cent methoxyflurane anaesthesia one of the dogs developed ventricular fibrillation and six others had ventricular tachycardia with an average duration of 27 seconds. When six of the nine survivors were subsequently given spinal analgesia, 2 per cent halothane anaesthesia, and epinephrine challenge, five developed ventricular fibrillation and the remaining dog had prolonged ventricular tachycardia.

None of the dogs given 1 per cent methoxyflurane anaesthesia (group II) developed ventricular fibrillation after epinephrine challenge though nine of the ten dogs had ventricular tachycardia with an average duration of 100 seconds. Three of the dogs, given 2 per cent halothane anaesthesia on a subsequent day, developed ventricular fibrillation after epinephrine challenge and died. The three "fresh" dogs also developed ventricular fibrillation and died.

\section{Discussion}

It was thought that cardiac irritability and irregularity is less under spinal anaesthesia than with ether, cyclopropane, or chloroform. ${ }^{8,9}$ On the other hand Goldberg showed that dogs given a total epidural ganglionic block with relatively large doses of local anaesthetic developed severe arrhythmias during hypothermia earlier than dogs without such block. ${ }^{10}$ However, these arrhythmias may have been due to the effect of the local anaesthetic reaching the blood stream from the epidural space, causing acceleration of heart rate. This is in agreement with the observations of Richardson and Walton, who observed that with moderate doses of intrathecal procaine there was no tachycardia, but when larger doses were used, tachycardia resulted. ${ }^{7}$

During well-conducted general anaesthesia little in the way of spontaneous arrhythmias is seen in the dog under cyclopropane, trichlorethylene, chloroform, halothane, the halothane-ether azeotrope, methoxyflurane, and trifluoroethylvinyl ether. ${ }^{11-14}$ If the dog is challenged with epinephrine during anaesthesia with these agents it has varying degrees of severe cardiac arrhythmias. During cyclopropane, trichlorethylene, and halothane anaesthesia most dogs develop severe and prolonged ventricular tachycardia or succumb with ventricular fibrillation. Methoxyflurâne or trifluoroethylvinyl ether cause milder arrhythmias after a standard epinephrine challenge.

It was evident from this study that spinal analgesia does not alter the type or 
severity of the arrhythmias seen atter epinephrine challenge when complared with similar experiments done in the same dog without spinal analgesia. Therefore high spinal analgesia per se gives no protection against the genesis of induced arrhythmias associated with general anaesthesia in the dog.

After hyperventilation none of the dogs anaesthetized with methoxyflurane sustained ventricular fibrillation although the dog may react in this manner after an epinephrine challenge. ${ }^{13,14}$ The duration of ventricular tachycardia under methoxyflurane anaesthesia during hyperventilation was longer than for the control series on the dogs under boţh spinal analgesia and methoxyflurane anaesthesia. The type and incidence of serious ventricular arrhythmias that occurred during hyperventilation under methoxyflurane anaesthesia were similar to those seen with methoxyflurane alone.

Each dog given 2 per cent halothane anaesthesia while it was being hyperventilated sustained ventricular fibrillation after epinephrine challenge. Of interest was the observation that under halothane anaesthesia during hyperventilation the pulse rate remained elevated whereas in all previous work under halothane anaesthesia the pulse rate fell sharply after 25 minutes of anaesthesia.

\section{Summary and Conclusions}

The effects of high spinal analgesia and hyperyentilation on the incidence of epinephrine-provoked cardiac arrhythmias were recorded electrocardiographically on dogs during anaesthesia with 1 per cent methoxyflurane and with 2 per cent halothane. It was obvious that neither spinal analgesia nor hyperventilation protects the heart of the dog from the potentially lethal effect of epinephrine when a stable level of anaesthesia is accomplished with methoxyflurane. During halothane anaesthesia, the epinephrine challenge is lethal in most instances.

\section{ACKNOWLEDGMENT}

This work was supported by a grant from Abbott Laboratories.

\section{RÉSUMÉ}

Les effets de l'analgésie rachidienne haute et de l'hyperventilation sưr la fréquence des arythmies cardiaques provoquées par l'épinéphrine ont été étudiés, chez des chiens soumis à l'anesthésie avec 1 pour cent de méthoxyflurane et 2 pour cent de fluothane, et, cela, sur un trace électrocardiographique. Il s'est avéré que ni l'analgésie rachidienne, ni l'hyperventilation, ne protège le cœur du chien contre l'effet mortel possible de l'épinéphrine, lorsque un plan stable d'anesthésie est obtenu avec le méthoxyflurane. Au cours de l'anesthésie au fluothane, la tentative d'administrer de l'épinéphrine est mortelle dans la plupart des cas.

\section{REFERENCES}

1. La Due, J. S.; Murison, P. J.; \& PACK, G. T. The Use of Tetraethylammonium Bromide as a Diagnostic Test for Pheochromocytoma. Ann. Int. Med. 29: 914 (1948).

2. Brфmage, P. R. \& Millar, R. A. Epidural Blockade and Circulating Catechol Amine Levels in a Child with Phaeochromocytoma. Ganad. Anaesth. Soc. J. 5: 282 (1958).

3. Real, C. E. New Plan in Operative Treatment of Patients with Severe Hyperthyroidism; Use of Spinal Anaesthesia. Surgery 16: 731 (1944) 
4. Lurie, A. A.; Jones, R. E.; Linde, H. W.; Prick, M. L.; Dripps, R. D.; \& Price, H. L. Cyclopropane Anesthesia: Cardiac Rate and Rhythm during Steady Levels of Cyclopropane Anesthesia at Normal and Elevated End Expiratory Carbon Dioxide. Anesthesiology 19: 457 (1958).

5. Price, H. L.; Lurie, A. A.; Black, G. W.; Sechzer, P. H.; Linde, H. W.; \& Price, M. L. Modification of General Anesthetics (Cyclopropane and Halothane) of Circulatory and Sympathoadrenal Responses to Respiratory Acidosis. Ann. Surg. 152: 1071 (1960).

6. Dobkin, A. B. The Takaoka Respirator for Automatic Ventilation of the Lungs. Canad. Anaesth. Soc. J. 8: 556 (1961).

7. Richardson, J. A. \& Walton, R. P. Cardiovascular Stimulation and Gut Depression during High Spinal Anaesthesia in Dogs without Premedication. J. Pharmacol. \& Exper. Therap. 107: 141 (1953).

8. Sмiтн, A. L. Action of Normal Hearts during Operative Procedures under Anesthesia as Studied by Graphic Visual and Auditory Methods. J. Internat. Coll. Surg. 6:386 (1943).

9. Green, N. M. Physiology of Spinal Anaesthesia, p. 37 et seq. Baltimore: Williams \& Wilkins Co. (1958).

10. Goldberg, L. I. \& Schmidy, K. F. Effect of Total Epidural Sympathetic Block on Cardiac Arrhythmias Developing during Hypothermia. Fed. Proc. 15: 429 (1956).

11. Dobkin, A. B. \& Purkin, N. The Effect of Perphenazine on Epinephrine-Induced Cardiac Arrhythmias in Dogs. I. Anaesthesia with Fluothane and the Fluothane-Ether Azeotrope. Canad. Anaesth. Soc. J. 6: 243 (1959).

12. Dobkin, A. B.; Donaldson, H.; \& Purkin, N. The Effect of Perphenazine on EpinephrineInduced Cardiac Arrhythmias in Dogs. II. Anaesthesia with Cyclopropane, Chloroform, and Trichlorethylene. Canad. Anaesth. Soc. J. 6: 251 (1959),2

13. IsraEL, J. S ; Criswick, V. G.; \& DoBkin, A. B. Effect of Epinephrine on Cardiac Rhythm during Anesthesia with Methoxyflurane $\left(\right.$ Penthrane $\left.^{\mathrm{R}}\right)$ and Trifluoroethylvinyl Ether (Fluoromar ${ }^{\mathbf{R}}$ ). Acta Scand. Anaesth. (in press).

14. Dobkin, A. B. \& Israel, J. S. The Effect of SA 97, Perphenazine, and Hydroxyzine on Epinephrine-Induced Cardiac Arrhythmias during Methoxyflurane Anaesthesia in Dogs. Canad. Anaesth. Soc. J. 9: 36 (1962). 